hechos y asimismo una explicación de los rasgos del naciente (o, como él escribe, del "renaciente") protestantismo español del ochocientos: una religión de marginados, fenómeno más rural que urbano, que arraigó entre las masas de pobres y de campesinos y que no produjo, salvo excepciones notorias (Usoz, Blanco White y muy pocos más), frutos intelectuales apreciables. Este protestan tismo inicial sufrió el durísimo ataque, que a veces provoca hechos esperpénticos, de una Iglesia católica caracterizada, ante todo, por su intolerancia y su ascasa capacidad de convicción y dado el sector social en que arraigó fue confundido en no pocas ocasiones con el socialismo o con cualquier tendencia surversiva. Duras condiciones, por tanto, que justifican el título del libro: la tolerancia y la libertad o, mejor aún, la intolerancia y la carencia de libertad fueron acompañantes consustanciales de los protestantes, extranjeros y españoles, que actuaron en la España de los primeros decenios del siglo XIX.

No desearíamos pasar por alto un aspecto sobresaliente del libro que comentamos: constituye una prueba de que las tesis de Menéndez Pelayo y de sus seguidores actuales, más o menos disimulados, acerca del carácter esencialmente católico de los españoles no deja de ser hoy una vanalidad y, ante todo, una inexactitud histórica. Los protestantes españoles tuvieron que luchar, precisamente, contra esos católicos intolerantes. Los términos de tal lucha están bien planteados en el libro de Vilar, que de manera global confirma y explica aportaciones de ámbito local que, como la muy sobresaliente de Josep Clara Resplandis dedicada a los protestantes de Girona (Diputació de Girona, 1994), dejan bien patente que la identificación entre español y católico no es sostenible.

En definitiva, este libro constituye una novedad importante que sin duda (permítasenos recurrir al tópico) llena un vacío considerable en nuestra producción historiográfica. La historia de la Iglesia en España no puede, a partir de ahora, circunscribirse a la católica y. menos aún. puede aducirse desconocimiento de lo que supuso una religión diferente pero de singular importancia en las sociedades modernas.

EMILIO LA PARRA LÓPEZ JOSE M. SANTACREU SOLER

\title{
REVOLUCIÓN DE 1868. SEXENIO DEMOCRÁTICO Y CANTONALISMO. NUEVAS APORTACIONES
}

El sexenio democrático constituye, sin duda, una de las etapas más sugerentes y atractivas para la investigación histórica del siglo XIX español, y ello ha tenido su reflejo en la que ya podemos calificar de abundante historiografía del período. La conmemoración de su centenario provocó una auténtica avalancha bibliográfica. prolongada en los años siguientes por el interés que despertaba una coyuntura democrática como el sexenio en el contexto de la transición a la democracia que vivía la sociedad española a finales de los setenta. Posteriormente, aunque ha disminuido el ritmo de publicaciones si lo comparamos con la eclosión anterior, el 
tema sigue acaparando la atención de los investigadores y, en las dos últimas décadas han ido apareciendo estudios que, presentados originariamente en su mayor parte como tesis doctorales y tesinas. se insertan en una renovada historia local o regional y han servido para profundizar, revisar y, en definitiva, para una mejor comprensión e interpretación de ese período crucial en nuestra centuria decimonónica.

En esta línea, el panorama historiográfico del sexenio democrático se ha visto últimamente enriquecido con algunas aportaciones de notable interés, que vamos a reseñar a continuación.

SERRANO GARCÍA. Rafacl: La Revolución de 1868 en Castilla y León. Valladolid, Secretariado de Publicaciones, Universidad de Valladolid, 1992, 361 pp.

El libro de R. Serrano García. que tiene su origen en su tesis doctoral, se centra en el análisis de la revolución del 68, entendida como la fase inicial del sexenio comprendida entre 1868 y 1870. y en el ámbito geográfico castellano-leonés. La elección de este marco territorial no parece fútil, no sólo por su contribución a la historia contemporánea de esa región. ni siquiera por las aportaciones que a las síntesis más generales ofrecen en nuevos enfoques y mayor profundidad y diversidad las monografías locales o regionales, sino porque en la historiografía actual del sexenio democrático se hacía necesaria la publicación de trabajos que analizasen el impacto y trayectoria de la revolución del 68 en una España interior caracterizada por lo menos, tópicamente- por su pasividad y por el tradicionalismo católico cuando no el reaccionarismo más integrista frente a la exaltación revolucionaria, laicista y republicana de la periferia peninsular en esta coyuntura. Desde esta perspectiva, el libro está bien planteado, expuesto con detalle y abundante información. pero acompañado de un notable esfuerzo de síntesis y reflexión, fruto de un laborioso trabajo de archivo -más de una veintena de archivos locales. provinciales y de carácter general- y de un eficaz manejo de la prensa de la época y de la bibliografía actual.

R. Serrano aporta, sin duda, interesantes conclusiones derivadas del análisis de varias cuestiones políticas, sociales y económicas -algunas de ellas ya planteadas en publicaciones anteriores'-, como son la formación y actuación de las Juntas Revolucionarias; la problemática social derivada de la crisis económica: mortalidad. mendicidad, paro, etc., y sus evidentes implicaciones políticas; o el problema del déficit de las haciendas locales y la polémica abolición de los consumos.

Sin embargo. pese a la importancia de estas cuestiones, las aportaciones más singulares de esta obra se centran en el análisis de las causas estructurales y

\footnotetext{
${ }^{1}$ SERRANO GARCÍA, R., El Se.venio revolucionario en Valladolid: Cuestiones sociales (1868-1874), Valladolid, 1986; "El retomo del impuesto de consumos en 1869-1870 como vía de financiación municipal: el caso de algunos Ayuntanientos castellano-leoneses", en Investigaciones Históricas, Universidad de Valladolid, n. 6, 1986, pp. 155-167.
} 
coyunturales de la crisis económica que, pese a su clásica catalogación como crisis de subsistencias o de "antiguo régimen" propia de una agricultura tradicional, el autor matiza, siguiendo las tesis de Garrabou y Sanz Fernández, al contemplar la intensa corriente de extracción de cereales y harinas fuera de la región como factor que agrava la coyuntura recesiva. que provoca el desmonte de las incipientes estructuras financieras e industriales de la zona y, sobre todo, el agotamiento del modelo de crecimiento del capitalismo agrario vigente desde 1820 , cuya consecuencia ulterior será la desorientación y pasividad de la sociedad castellana en la conspiración y el pronunciamiento septembrino.

Del mismo modo, a juicio de R. Serrano, el agotamiento de este modelo económico regional determina la pasividad de la burguesía cerealista $\mathrm{y}$ harinera castellana frente a la modificación de la política arancelaria y, en definitiva, pone de relieve su incapacidad para adaptarse al nuevo marco de relaciones económicas y sociales del sexenio y para asumir un nuevo modelo de crecimiento económico que comienza a esbozarse, no obstante, en la Asociación agricola por la iniciativa privada a impulsos de un sector más dinámico de la burguesía local. Así, concluye el autor, "la burguesía harinera se legitimaba aún más como portadora de los auténticos intereses de Castilla".

PIQUERAS ARENAS, José A.: La Revolución democrática (1868-1874). Cuestión social, colonialismo y grupos de presión. Madrid, Centro de Publicaciones del Ministerio de Trabajo y Seguridad Social, 1992, 848 pp.

Esta obra, que recoge la tesis doctoral de su autor, aborda el sexenio desde su conclusión final con el objetivo central de analizar los orígenes sociales de la Restauración. La circunstancia histórica de que ésta tuviese su origen en un pronunciamiento militar en Sagunto preparado por una amplia trama conspirativa de la burguesía local hacen de Valencia un escenario privilegiado para el historiador y le permiten reconstruir el proceso con un denso, minucioso y documentado estudio que, utilizando el método del materialismo histórico, se centra en el sexenio democrático y la reacción conservadora que conduce a su final. Se trata, pues, de un trabajo que nace de un enfoque local pero que, por la amplia y variada documentación inédita que utiliza, el análisis efectuado y las conclusiones a las que llega, lo rebasa ampliamente para configurarse como una obra notable, sugerente y controvertida dentro del panorama historiográfico y la bibliografía actual del sexenio y los orígenes de la Restauración y. en cierta forma, la continuación de una línea de investigación que ha fructificado en dos trabajos anteriores en colaboración con $\mathrm{E}$. Sebastiá2.

Considerando el sexenio como la última fase del proceso revolucionario burgués,

\footnotetext{
${ }^{2}$ SEBASTIÁ, E.: PIQUERAS, J.A.. Pervivencias feudales y revolución democrática. Valencia, 1987. y Agiotistas, negreros y partisanas. Dialéctica social en visperas de la Revolución Gloriasa. Valencia. 1991.
} 
Jose A. Piqueras se adentra en la problemática del período centrándose, en especial, en sus aspectos democratizadores y profundamente reformistas y las consecuencias sociales y políticas que de ellos se derivan, sobre todo aquellas que inciden directamente en la reacción conservadora que cierra el ciclo revolucionario. Estructurado el trabajo en tres partes, en la primera se trata la formación del movimiento obrero valenciano, atendiendo fundamentalmente a la influencia de la "cuestión social" y la figura de Pérez Pujol y al nacimiento de la Internacional. En este punto. y aunque se señale el peso de la tradición republicana, cabría insistir más en su arraigo y pervivencia como referencia política e incluso ideológica en el obrerismo valenciano -y español, por extensión-; lo que no significa minusvalorar la importancia que en la dimensión social tiene el sexenio como fin del ciclo revolucionario liberal y punto de arranque de la articulación política e ideológica de las clases subaltemas, de la organización del proletariado y de su irrupción en la escena social y política como portador de un proyecto revolucionario de contenido distinto al de la burguesía.

En una segunda parte, se aborda la cuestión colonial y la esclavitud, analizandola desde su dimensión económica y la trama de intereses que en torno a ella se entretejen, con especial atención al proyecto abolicionista planteado en el sexenio y a la reacción que provoca en los sectores y clases ligados a estos intereses económicos.

Concluye el trabajo, con un amplio apartado -desde nuestro punto de vista, el de mayor enjundia- dedicado al análisis de aquella fracción burguesa que, privada del poder desde 1868, dirige la acción restauradora y se convierte en la columna vertebral del nuevo régimen impuesto en 1874, por lo menos en sus primeros años: "Los vencidos de 1868 (...) son los conspiradores y los vencedores de 1874", en palabras del propio autor, que identifica a esta fracción conservadora con el conjunto de la burguesía -probablemente por una sobrevaloración del componente democrático, popular y obrero de la revolución-, lo que, en nuestra opinión, sería discutible.

Resulta evidente que una fracción de la burguesía española -aquella que protagonizó la revolución liberal y sustentó el régimen isabelino- se ve marginada con la revolución del 68; sin embargo, no toda la burguesía es moderada o unionista, como afirma Piqueras, los progresistas y, en menor medida, los demócratasrepublicanos también representan políticamente a sectores influyentes de la burguesía, aunque presenten en su base social un importante componente popular y pequeñoburgués. No podemos olvidar la existencia de diferentes fracciones y su lucha por el poder en el seno de la clase dominante y los desajustes que el estrecho marco oligárquico isabelino está produciendo entre el bloque de poder y su representación política, factor muy destacable, en opinión, de algunos autores como motor de la revolución. Desde este enfoque más amplio, es posible abordar el fenómeno del 68 en toda su complejidad. La revolución no fue obra exclusiva de la pequeña burguesía y las clases populares, sino que contó con la activa participación y adhesión de parte de la burguesía que. en una coyuntura de recesión económica generalizada desde 1866 y descontenta con el estrecho marco político y económico isabelino que limitaba su acceso a la escena política y frenaba el desarrollo integral capitalista, se inclinó hacia la revolución. Del mismo modo, el triunfo de la Restauración no puede 
entenderse únicamente como la reacción conservadora de aquella fracción que nunca se identificó con el 68, por mucho que a ella debiera su impulso inicial, sino que la larga duración y estabilidad del nuevo régimen sólo es explicable por la consecución de un consenso amplio entre las diversas fracciones de las clases dominantes. La decantación de parte de la burguesía septembrina -progresistas (constitucionales)hacia una "salida de orden" frente al radical proceso de democratización del Estado y la sociedad esbozado en 1873 es clara y, en muchos casos, vemos como los revolucionarios del 68 fueron los restauradores de 1874, 1879 o $1881^{3}$.

En la parte final del libro, que constituye, sin duda, su principal aportación -y no sólo para el conocimiento de las élites burguesas valencianas decimonónicas- se realiza un exhaustivo y pormenorizado análisis de esa burguesía que apuesta por la Restauración, de sus perfiles sociales, económicos y de comportamiento político; de su relación con otras fracciones dominantes; del origen y evolución de su patrimonio y negocios y, en definitiva, de su capacidad de reorganización y movilización a través de diversas asociaciones y grupos de presión en defensa de sus intereses específicos como el Centro Hispano Ultramarino, la Liga Nacionalista Colonialista o, especialmente. la Liga de Propietarios de Valencia que será, como demuestra esta investigación, el instrumento decisivo para la acción política de este grupo y para la gestación del movimiento restaurador.

Actas de las Jornadas sobre el Sexenio Revolucionario y el Cantón Murciano, en Anales de Historia Contemporánea (Monografico sobre el Sexenio Revolucionario y el Cantón Murciano coordinado por Antonio J. Mula Gómez), $\mathrm{n}^{\circ} 9$ y 10, Universidad de Murcia, Murcia, 1993-1994, 604 pp.

Esta obra, de muy reciente aparición, recoge las actas de las Jornadas de Historia sobre el Cantón Murciano (VIII Curso de Aproximación a la España Contemporánea) que, celebradas en Murcia y Cartagena en abril de 1993, fueron organizadas por el Departamento de Historia Moderna. Contemporánea y de América bajo la dirección del profesor Juan Bautista Vilar.

Las actas de las Jornadas -que contaron con la participación de diversos departamentos, centros de investigación y Universidades españolas y extranjeras, así como de prestigiosos especialistas en la materia- incluyen gran parte de las ponencias, comunicaciones y colaboraciones presentadas, aunque algunas han sido excluídas por haberse publicado con anterioridad a esta edición, y constituyen una interesante aportación a la ya prolija historiografía del sexenio democrático por tratarse de un buen exponente de las actuales líneas de investigación y del interés que sigue despertando en nuestros historiadores este período tan complejo y decisivo en

\footnotetext{
${ }^{3}$ En este sentido, resulta clarificador que, dentro del propio ámbito geográfico valenciano, en Alicante, por ejemplo, el principal frente de formación del conservadurismo canovista lo constituyan un grupo de ex-constitucionales del sexenio que desplazan a moderados y unionistas. Véase al respecto, ZURITA ALDEGUER, R., El Marqués del Basch y el conservadurismo alicantino. Tesis Doctoral inédita, Universidad de Alicante, 1994.
} 
la configuración de la España contemporánea.

La voluminosa extensión de las actas, publicadas como número monográfico en dos volúmenes de la revista Anales de Historia Contemporánea, no permiten, como hubiese sido deseable, el análisis pormenorizado de cada uno de los trabajos incluidos, pero sí podemos comentar las distintas temáticas que ofrecen, destacando en ellas las principales aportaciones.

En el capítulo dedicado a la interpretación, metodología y fuentes, destacaríamos el trabajo de J. A. Lacomba en el que, a propósito del caso andaluz, reflexiona sobre el cantonalismo como protesta revolucionaria, la revolución del 68 con sus diversos objetivos y niveles de acción y el alcance del sexenio en la conformación de la España contemporánea. En el mismo capítulo, es de gran utilidad el balance que sobre la historiografía del sexenio efectua $\mathrm{M}$. Urquijo Goitia que, centrándose en aquellas obras menos conocidas por su carácter local o regional, viene a completar análisis bibliográficos anteriores, como los de Guereña o De la Fuente Monge.

El tema de la prensa. que en el sexenio tuvo un desarrollo espectacular por la intensa agitación política, es recogido en las comunicaciones de M.S. Arroyo y J. Alcaraz, que versan sobre la prensa murciana en el sexenio y la imagen del Cantón en la prensa gráfica, respectivamente. Muy interesante por su enfoque metodológico resulta la colaboración de J. Sánchez González que, a partir de la metodología de la "topología del discurso" del profesor A. Rodríguez de las Heras y la "teoría de la informacion", trata de aproximarse a la mentalidad de los federales extremeños.

En las actas, la historia política, ideológica y de las relaciones internacionales tiene su representación en varias comunicaciones sobre diversos aspectos del Cantón y del movimiento cantonalista. como las de Egea Bruno, Roda Alcantud, Iniesta Magán y Victoria Moreno. Entre las ponencias, destacaríamos la de L. Alvarez Gutiérrez, que analiza. desde la perspectiva de las relaciones internacionales y la política de Bismark, la intervención naval alemana contra el Cantón Murciano y, especialmente, la de J. B. Vilar centrada en la génesis, organización y evolución del federalismo y el partido republicano murciano, con especial atención a la figura de Antonio Gálvez Arce, uno de los líderes más carismáticos del cantonalismo.

Dentro de la historia local y regional, la evolución del sexenio en distintas comarcas o localidades ha sido abordada en las comunicaciones de Mula Gómez, Martínez Mercader. Sánchez Romero y Ludeña López que, enmarcadas por la valoración general del fenómeno cantonalista en la región murciana que realiza Pérez Crespo, nos ofrecen, en líneas generales, una periferia regional agraria notablemente influida por el tradicionalismo monárquico, centralista y de la Iglesia, y hostigada continuamente por la actividad carlista y contrarrevolucionaria; una imagen muy alejada, por tanto, de la que muestra el foco revolucionario de Murcia y Cartagena.

Tampoco ha sido desalendida en estas actas la historia social y económica, como muestran las comunicaciones de Rubio Paredes sobre las fuentes demográficas de la Cartagena cantonal; Gómez. Vizcaíno sobre las bajas del Cantón: Román Cervantes sobre la agricultura cartagenera; Segura Artero sobre la desamortización; Gutiérrez Lloret sobre la crisis económica y la coyuntura revolucionaria del 68; Sánchez. Marroyo sobre la dialéctica de confrontación y violencia social en el campo extremeño; y finalmente, las de J.B.Vilar y De Maya Ruíz y Robles Jaén sobre las 
dificultades de las haciendas locales, el fracaso del sistema fiscal alternativo (impuesto personal) y el restablecimiento de los impopulares consumos.

La cuestión monetaria en este período se trata en las comunicaciones de Saínz Ortega y, en especial, de Santacreu Soler que, desde un innovador enfoque, analiza la revolución monetaria del 68. atendiendo a la ruptura que en la simbología de las monedas acuñadas supone el sexenio democrático y que representa en la iconografía del numerario español el tránsito de la Monarquía Hispánica al Estado liberal.

En último lugar, cabe citar un apartado de colaboraciones planteado desde la perspectiva de la relación entre historia y literatura con comunicaciones de Molina Martínez, Henares Díaz, Rubio Paredes, Rodríguez Rubio y Ríos Sánchez, que estudian el Cantón en su dimensión literaria y las memorias y manifiestos de sus protagonistas o coetáneos, destacando especialmente el análisis comparado que efectua el profesor B. Barrére de las dos imágenes literarias del Cantón creadas en sus obras por Pérez Galdós y Sénder.

ROSA ANA GUTIERREZ LLORET 